$\mathrm{DOI}$

(C) Д. В. КОЗАК

ДВНЗ “Тернопільський державний медичний університет імені І. Я. Горбачевського”

\title{
Вплив політравми на динаміку раннього і пізнього апоптозу лімфоцитів тканини серця
}

\author{
D. V. KOZAK \\ SHEI "Ternopil State Medical University by I. Ya. Horbachevsky"
}

\section{THE IMPACT OF POLYTRAUMA ON DYNAMICS OF EARLY AND LATE LYMPHOCYTE APOPTOSIS} AT HEARTS' TISSUE

\begin{abstract}
Робота присвячена вивченню апоптозу лімфоцитів тканини серця у динаміці експериментальної політравми. Показано, що в умовах політравми різко збільшується інтенсивність раннього і пізнього апоптозу лімфоцитів тканини серця впродовж 28 діб посттравматичного періоду та відзначено загальну закономірність зростання інтенсивності раннього апоптозу протягом 7 діб посттравматичного періоду зі зниженням через 14 діб, наступним повторним, проте меншим, підвищенням через 21 добу і зниженням через 28 діб.

The work is devoted to the study of experimental trauma on dynamics lymphocytes apoptosis of the heart tissue. It is shown that in a polytrauma dramatically increases the intensity of early and late lymphocytes apoptosis of heart tissue during the 28 days post-traumatic period and the overall pattern of increasing intensity of early apoptosis for 7 days post-traumatic period with a reduction in 14 days, followed by repeated, but smaller, increase after 21 days and reduction in 28 days.
\end{abstract}

Постановка проблеми і аналіз останніх досліджень та публікацій. Важливим досягненням останніх років $€$ доведення провідної ролі в патогенезі травматичної хвороби генералізації запальної реакції під впливом прозапальних цитокінів із формуванням синдрому поліорганної недостатності [1]. Окремі автори вважають, що одним із провідних механізмів переходу системної відповіді організму на запалення до поліорганної недостатності $є$ програмована клітинна загибель - апоптоз, який розвивається в органах, що зазнають запального впливу [2]. Однак дотепер немає переконливих даних щодо ролі апоптозу у формуванні поліорганної недостатності.

Дослідження динаміки прозапальних цитокінів як індукторів апоптозу у постраждалих із тяжкою політравмою показало, що в ранньому посттравматичному періоді спостерігається висока концентрація проапоптичних цитокінів, яка до 7-10-ї доби знижується із поступовим підвищенням антиапоптичних цитокінів [3]. Разом з тим вважають, що цитокіни $є$ тільки ранніми сигнальними молекулами, які належать до пускових механізмів подальших патологічних процесів, i їх інтенсивність утворення не завжди відповідає тяжкості перебігу полі- травми [1], що спонукає до вивчення безпосередніх проявів апоптозу паренхіматозних клітин.

Одними із найчутливіших клітин організму до проапоптичного впливу цитокінів є лімфоцити. Збільшення їх апоптозу зумовлює згасання інтенсивності запальної реакції та зумовлює розвиток імуносупресії у посттравматичному періоді [4]. Враховуючи, що лімфоцити постійно циркулюють між кров'ю і тканинами, на сьогодні існує методичний підхід, згідно з яким апоптоз тканинних лімфоцитів відображає сукупність впливу прозапальних цитокінів на рівні органа, що дозволяє оцінити й глибину апоптозу клітин органів і тканин [5, 6, 7].

Мета роботи: з'ясувати інтенсивність раннього і пізнього апоптозу лімфоцитів, отриманих із тканини серця в динаміці політравми.

Матеріали і методи. В експериментах використано 109 нелінійних білих щурів, яких утримували на стандартному раціоні віварію. 20 тварин складали контрольну групу. В дослідних групах було по 8-14 особин.

Політравму моделювали за методикою Д. В. Козак (2011) [8] в умовах тіопентало-натрієвого зне- 
болювання (40 мг $\cdot \mathrm{K}^{-1}$ маси тіла тварини). Зміст моделі полягав у тому, що в наркотизованого щура спершу викликали зовнішню кровотечу зі стегнової вени, яка в середньому становила 20-22 \% об’єму циркулюючої крові. Аутокров у дозі 0,5 мл на 100 г маси тварини вводили шприцом внутрішньоочеревинно для формування гемоперитонеуму. Далі ламали стегнову кістку. Рану на стегні зашивали.

Тварин, що залишились живими, виводили 3 експерименту через 2 год, 1, 3, 7, 14, 21 і 28 діб методом тотального кровопускання із серця в умовах знеболювання. Для виділення тканинних лімфоцитів промите в фосфатно-сольовому буфері серце гомогенізували в подрібнювачі тканин, гомогенат центрифугували 20 хв при 8000 об/хв. 3 надосадової рідини виділяли фракції лімфоцитів на градієнті щільності фікол-тріумбрасту 1,077. Для оцінки реалізації апоптозу лімфоцитів серця використовували ФІТЦ-мічений анексин V з набору реагентів “ANNEXIN V FITC” (“Beckman Coulter”, Франція). Аналіз проб проводили на проточному цитометрі Epics XL (“Beckman Coulter”, Франція).

Під час роботи з лабораторними тваринами дотримувались міжнародних вимог про гуманне поводження з тваринами відповідно до правил “Європейської конвенції захисту хребетних тварин, яких використовують з експериментальною та іншою науковою метою” (European Convention, 1984); методичних рекомендацій ДФЦ МОЗ України про “Доклінічні дослідження лікарських засобів”.

Одержаний цифровий матеріал обробляли з використанням критерію Стьюдента в разі нормального розподілу порівнюваних статистичних сукупностей та непараметричного критерію Манна-Уїтні при відсутності нормального розподілу. Відмінності вважали достовірними при вірогідності нульової гіпотези не більше $5 \%$ (p $\leq 0,05)$.
Результати досліджень та їх обговорення. Як видно 3 таблиці 1 і рисунка 1, в умовах моделювання політравми порівняно з контрольною групою різко збільшувалася інтенсивність раннього апоптозу лімфоцитів тканини серця протягом усього терміну спостереження від 2 год до 28 діб посттравматичного періоду $(\mathrm{p}<0,05)$. Характерною рисою раннього апоптозу лімфоцитів серця були його коливальні відхилення: показник до 7-ї доби після нанесення політравми зростав, далі через 14 діб знижувався з наступним повторним, проте меншим за амплітудою підвищенням через 21 добу і зниженням через 28 діб. Через 7 діб показник виявився статистично достовірно більшим, ніж в усі попередні терміни спостереження ( $<0,05)$. Через 14 діб досягав рівня 2 год спостереження $(\mathrm{p}>0,05)$. Через 21 добу ставав істотно більшим і досягав рівня 1-ї доби посттравматичного періоду (p>0,05), що виявилося статистично вірогідно більшим, ніж через 2 год, 3 і 7 діб (p<0,05), проте не досягало рівня 7-ї доби $(\mathrm{p}<0,05)$. Через 28 діб показник повторно знижувався порівняно з попереднім терміном спостереження $(\mathrm{p}<0,05)$.

У свою чергу, пізній апоптоз лімфоцитів серця (табл. 1, рис. 2) у дослідних групах у всі терміни посттравматичного періоду суттєво перевищував рівень контролю $(\mathrm{p}<0,05)$. Через 2 год, 1 і 3 доби даний показник поступово зростав, проте результат виявився статистично не достовірним між цими групами (p>0,05). Через 7 діб відмічався спалах пізнього апоптозу лімфоцитів серця - у 12,3 раза стосовно контролю $(\mathrm{p}<0,05)$ та істотно перевищував аналогічну величину попередніх термінів спостереження $(\mathrm{p}<0,05)$. Через 14 діб величина даного показника значно зменшилася і всього на 38,5 \% перевищувала рівень контролю $(\mathrm{p}<0,05)$ та виявилася істотно меншою порівняно з усіма попередніми термінами спостереження ( $<<0,05)$. В подальшому,

Таблиця 1. Динаміка інтенсивності раннього і пізнього апоптозу лімфоцитів тканини серця у відповідь на політравму $(\mathrm{M} \pm \mathrm{m})$

\begin{tabular}{|c|c|c|c|c|c|c|}
\hline $\begin{array}{l}2 \text { год } \\
(\mathrm{n}=6)\end{array}$ & $\begin{array}{l}\text { 1-ша доба } \\
(\mathrm{n}=8)\end{array}$ & $\begin{array}{l}\text { 3-тя доба } \\
(\mathrm{n}=5)\end{array}$ & $\begin{array}{l}\text { 7-ма доба } \\
(\mathrm{n}=6)\end{array}$ & $\begin{array}{l}\text { 14-та доба } \\
\quad(\mathrm{n}=6)\end{array}$ & $\begin{array}{l}\text { 21-ша доба } \\
\quad(\mathrm{n}=6)\end{array}$ & $\begin{array}{c}\text { 28-ма доба } \\
(\mathrm{n}=5)\end{array}$ \\
\hline \multicolumn{7}{|c|}{$\begin{array}{c}\text { Ранній апоптоз лімфоцитів серця } \\
\text { Контроль }=(0,35 \pm 0,02) \text { мкмоль } \cdot \pi^{-1}(\mathrm{n}=20)\end{array}$} \\
\hline $\begin{array}{l}6,85 \pm \\
0,54^{*}\end{array}$ & $\begin{array}{c}10,72 \pm \\
0,93^{*}\end{array}$ & $\begin{array}{c}9,41 \pm \\
0,32^{*}\end{array}$ & $\begin{array}{c}40,37 \pm \\
1,88^{*}\end{array}$ & $\begin{array}{c}7,92 \pm \\
0,54^{*}\end{array}$ & $\begin{array}{c}11,37 \pm \\
0,56^{*}\end{array}$ & $\begin{array}{l}8,96 \pm \\
0,95^{*}\end{array}$ \\
\hline \multicolumn{7}{|c|}{$\begin{array}{l}\text { Пізній апоптоз лімфоцитів серця } \\
\text { Контроль = }(0,52 \pm 0,05) \%(\mathrm{n}=20)\end{array}$} \\
\hline $\begin{array}{l}1,11 \pm \\
0,13^{*}\end{array}$ & $\begin{array}{l}1,35 \pm \\
0,04^{*}\end{array}$ & $\begin{array}{l}1,65 \pm \\
0,27^{*}\end{array}$ & $\begin{array}{c}6,38 \pm \\
0,64^{*}\end{array}$ & $\begin{array}{l}0,72 \pm \\
0,07^{*}\end{array}$ & $\begin{array}{l}1,05 \pm \\
0,21^{*}\end{array}$ & $\begin{array}{c}2,90 \pm \\
0,20^{*}\end{array}$ \\
\hline
\end{tabular}

Примітка. ${ }^{*}$ - відмінності стосовно контрольної групи статистично достовірні (p<0,05). 


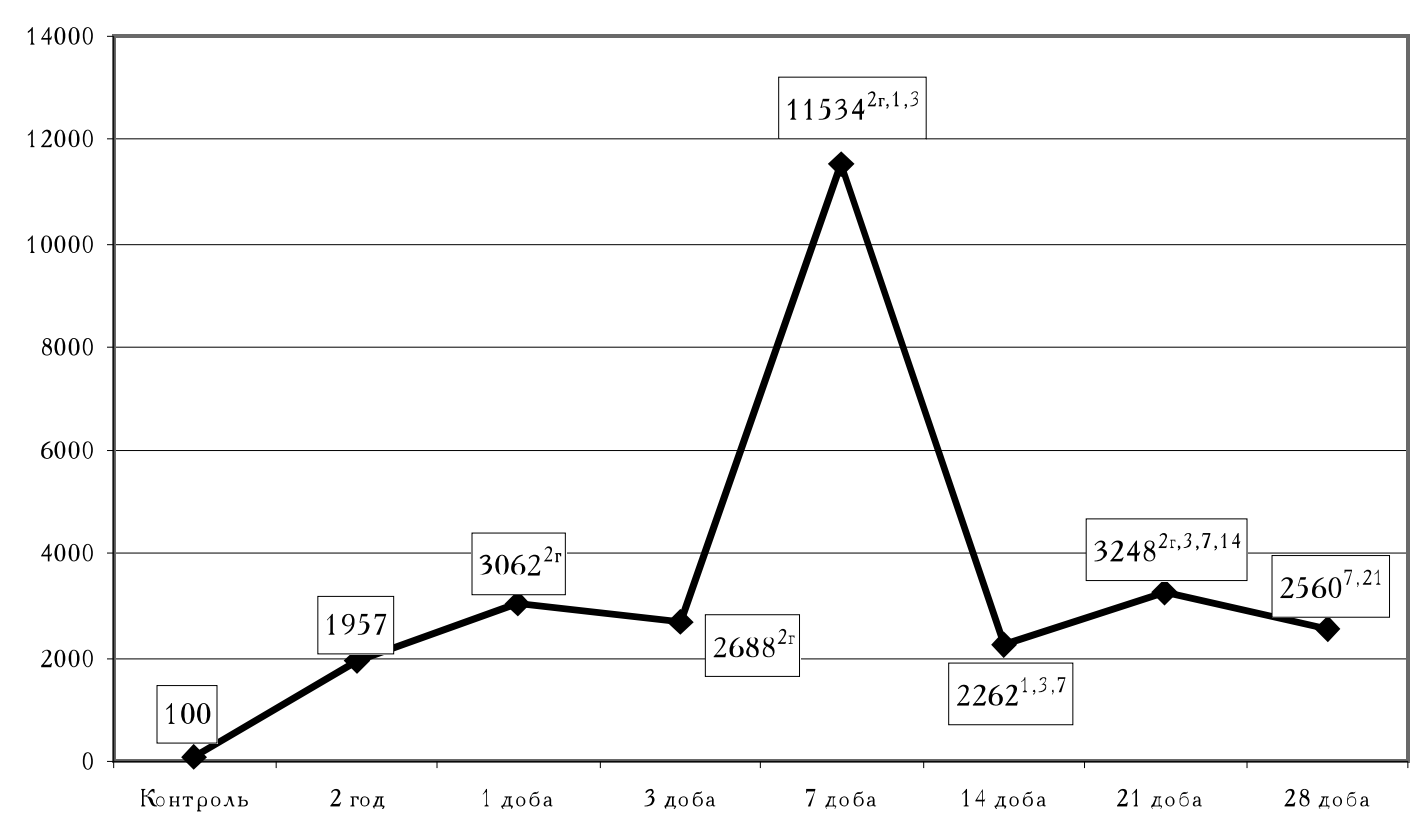

Рис. 1. Ранній апоптоз лімфоцитів серця в динаміці політравми (у відсотках до рівня контролю). (Тут і на рисунку 2: 2г, 1, 3, 7, 14, 21 і 28 - відмінності стосовно показника тварин, відповідно, через 2 год, 1, 3, 7, 14, 21 і 28 діб після нанесення політравми статистично достовірні $(\mathrm{p}<0,05))$.

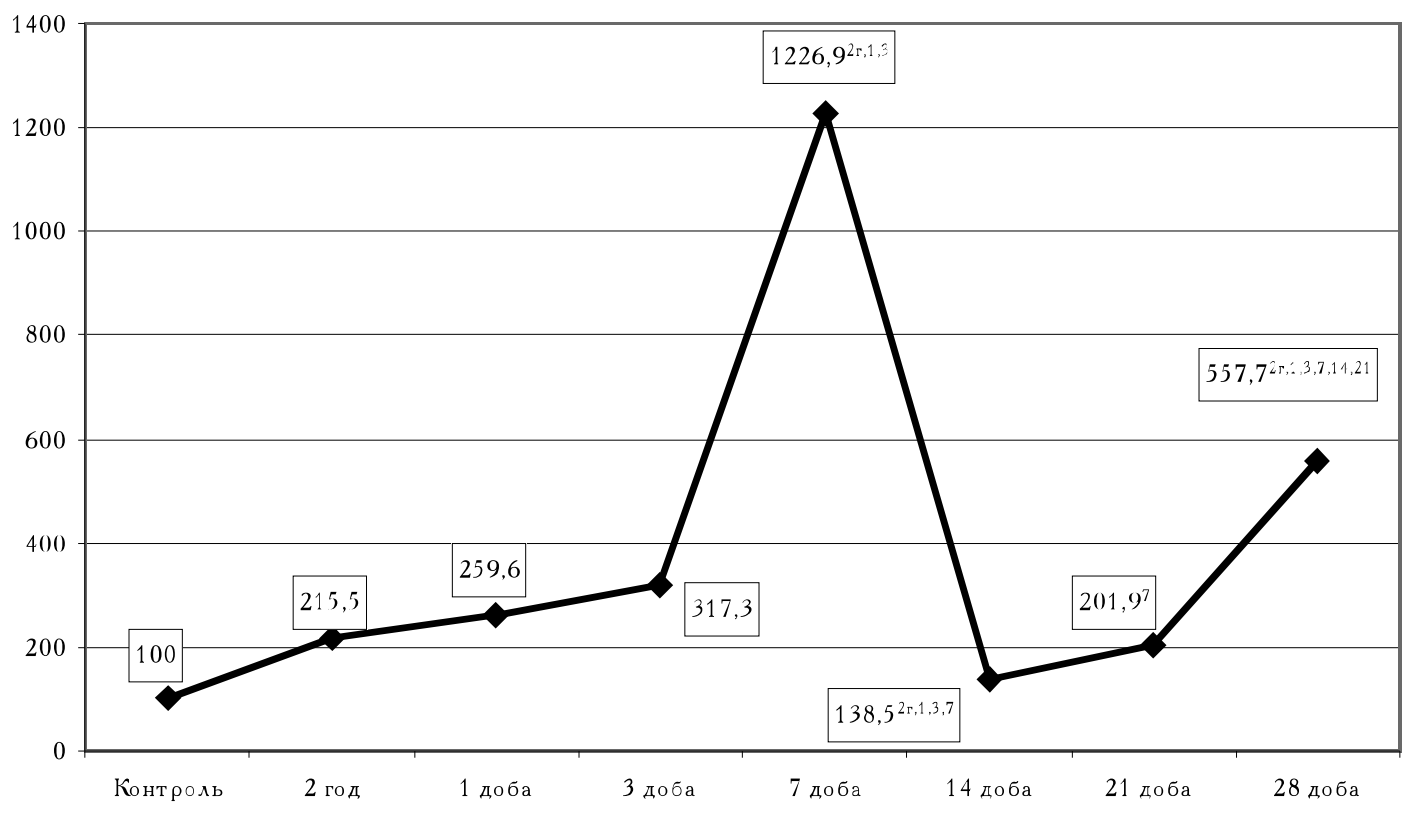

Рис. 2. Пізній апоптоз лімфоцитів серця у динаміці політравми (у відсотках до рівня контролю).

через 21 і 28 діб, показник знову збільшувався, досягаючи в кінці експерименту рівня, який в 5,57 раза вищий від контролю ( $<0,05)$, й перевищує аналогічний рівень на 2 год, 1-шу, 3-тю, 14-ту і 21-шу доби ( $<0,05)$, проте залишається суттєво меншим, ніж на 7-му добу, - на 54,5 \% ( $<<0,05)$.

Враховуючи, що ранній апоптоз є наслідком впливу на тканини про- і протизапальних цитокі- нів, можна припустити, що в умовах травми регуляторні механізми тканини серця більше обмежують інтенсивність раннього апоптозу впродовж перших трьох діб посттравматичного періоду. На сьому добу настає спалах інтенсивності раннього апоптозу, що вказує на потужний проапоптозний вплив, виснаження механізмів антиапоптозного захисту й свідчить як про розвиток імуносупресії, 
так і ураження міокардіоцитів, що підтверджується нашими морфологічними дослідженнями [9] 3 можливістю розвитку серцевої недостатності. Подальше зниження інтенсивності раннього апоптозу може свідчити про розвиток компенсаторного синдрому антизапальної відповіді, на тлі якого починають переважати протизапальні цитокіни [10].

Наступний спалах раннього апоптозу тканинних лімфоцитів є свідченням фазовості посттравматичного періоду, пов'язаний із завершенням терміну формування імунологічної відповіді на пошкодження, яка супроводжується стимуляцією утворення проапоптозних цитокінів. Подібний феномен загострення через 21 добу показаний на тлі експериментальної кріотравми шкіри [11].

Достатньо високий рівень раннього апоптозу тканинних лімфоцитів на 28-му добу вказує на те, що відновлення тканин після політравми ще далеке від свого завершення. Це не може не відобразитися на ступені дистрофічних процесів у тканині серця в цей термін посттравматичного періоду.

Паралельно відбувається й активація пізнього (необоротного) апоптозу лімфоцитів тканини серця. Отже, сукупність патогенетичних меха-

\section{СПИСОК ЛІТЕРАТУРИ}

1. Калинкин О. Г. К патогенезу травматической болезни / О. Г. Калинкин, А. О. Калинкин // Проблеми військової охорони здоров'я. - 2002. - С. 34-43.

2. Fearon D. T. The instructive role of innate immunity in the acquired immune response / D. T. Fearon, R. M. Locksley // Science. - 1996. - Vol. 272. - P. 50-53.

3. Дзюба Д. А. Показатели активации апоптоза в течении политравмы тяжелой степени / Д. А. Дзюба, И. Р. Малыш, Л. В. Згржебловская // Український журнал екстремальної медицини імені Г. О. Можаєва. - 2008. - Т. 9, № 1. - С. 53-58. 4. Ingibition of Fas/Fas ligand signaling improves septic survival: differential effects on macrophage apoptotic and functional capacity / C. S. Chang, G. Y. Song, J. Lomas [et al.] // J. Leukoc. Biol. - 2003. - Vol. 74 (3). - P. 344-351.

5. Козак Д. В. Вплив політравми на динаміку раннього апоптозу тканинних лімфоцитів / Д. В. Козак, А. А. Гудима // Медична хімія. - 2012. - Т. 14, № 3 (52). - С. 86-88.

6. Козак Д. В. Вплив політравми на динаміку пізнього апоптозу тканинних лімфоцитів / Д. В. Козак, А. А. Гудима // Клінічна хірургія. - 2013. - № 9 (848). - С. 70-72. нізмів політравми створює передумови для реалізації як раннього, так і пізнього - необоротного апоптозу тканинних лімфоцитів. Можна припустити, що саме пізній апоптоз лежить в основні розвитку органної дисфункції і недостатності. Враховуючи значний відсоток раннього і пізнього апоптозу лімфоцитів тканини серця із розвитком дистрофічно-некротичних порушень міокардіоцитів, можна припустити, що аналогічні відхилення можуть виникати й у скелетних м'язах.

Висновки. В умовах політравми різко збільшується інтенсивність раннього і пізнього апоптозу лімфоцитів тканини серця впродовж 28 діб посттравматичного періоду. Загальною закономірністю $€$ зростання інтенсивності раннього апоптозу через 7 діб після політравми зі зниженням через 14 діб, з наступним повторним, проте меншим, підвищенням через 21 добу і зниженням через 28 діб.

Перспективи подалыших досліджень. У перспективі важливим є дослідження в умовах політравми раннього і пізнього апоптозу м’язової тканини 3 метою розробки адекватних технологій реабілітації.

7. Волотовська Н. В. Вплив експериментальної травми різного ступеня тяжкості на структуру печінки та апоптоз печінкових макрофагів / Н. В. Волотовська // Український науково-медичний журнал. Спеціальний випуск. - 2012. № 3. - С. 408-409.

8. Пат. 63997 Україна, МПК G 09 В 23/28. Спосіб моделювання політравми / Козак Д. В. ; заявник і патентовласник Тернопільський державний медичний університет імені І. Я. Горбачевського. - № u 201104110 ; заявл. 05.04.11 ; опубл. 25.10.11, Бюл. 20.

9. Козак Д. В. Динаміка структурних змін тканини міокарда у періоди ранніх і пізніх проявів експериментальної травматичної хвороби / Д. В. Козак // Вісник морфології. - 2014. Т. 20, № 1. - С. 136-140.

10. Bone R. C. Sir Isaac Newton, sepsis, SIRS, and CARS / R. C. Bone // Crit. Care Med. - 1996. - Vol. 24. - P. 1125-1128. 11. Гудима А. А. Порушення морфофункціонального стану печінки в умовах локальної кріодеструкції шкіри та його корекція / А. А. Гудима, О. Б. Сван, Т. В. Дацко // Здобутки клінічної і експериментальної медицини. - 2007. - № 2. С. 183-188.

Отримано 14.07.15 